\title{
"UPAYA PEMANFAATAN HALAMAN RUMAH SEBAGAI LAHAN PERTANIAN TANAMAN BUDIDAYA UNTUK KEBUTUHAN KONSUMSI DAN PEMASARAN MASYARAKAT PADA MASA COVID 19 DI KELURAHAN TEMPULING"
}

\author{
Razy Syahputra ${ }^{1}$ \\ ${ }^{1}$ Jurusan Agroteknologi, Fakultas Pertanian, Universitas Islam Indragiri, Tembilahan \\ Email: razisyahputra72@gmail.com
}

\begin{abstract}
The purpose of this study was to utilize the empty or non-functional home page as a means of agricultural land that can have a sale and consumption value on the planted crops and reduce the spread of the covid-19 chain in the Tempuling village and fulfill the government's recommendation to stay home only. This research was conducted by means of interviews and discussions consisting of 7 samples and the population in the Tempuling Village. The conclusion from the method carried out is that homeyard farming has the potential to support or replace agriculture on land during the Covid 19 period, where all activities outside the home must be limited by the government to break the chain of Covid 19. This cultivation is carried out on a small scale and is prioritized to meet household needs.
\end{abstract}

Keywords: Home page, agriculture, covid-19, cultivation.

\begin{abstract}
Abstrak
Tujuan Penelitian ini adalah untuk memanfaatkan halaman rumah yang kosong atau tidak memiliki fungsi sebagai sarana lahan pertanian yang dapat memiliki nilai jual dan konsumsi pada tanaman yang di tanam serta mengurangi penyebaran mata rantai covid-19 di kelurahan Tempuling dan memenuhi anjuran pemerintah untuk di rumah saja. Penelitian ini di lakukan dengan metode wawancara dan diskusi yang terdiri dari 7 orang sampel dan populasi yang ada di Kelurahan Tempuling. Kesimpulan dari metode yang di lakukan di dapat bahwa pertanian halaman rumah sangat berpotensi sebagai penunjang atau pengganti pertanian di lahan pada masa covid 19 ini, yang mana segala aktifitas di luar rumah sangat harus di batasi oleh pemerintah guna memutus mata rantai covid 19. Budidaya ini dilakukan dalam skala kecil dan diutamakan untuk memenuhi kebutuhan rumah tangga.
\end{abstract}

Kata kunci: Halam rumah, pertanian, covid-19, budidaya.

\section{Pendahuluan}

Masa pandemi COVID-19 memaksa setiap orang untuk tinggal di rumah demi memutus mata rantai penyebaran virus. Kondisi ini tidak serta merta membuat para petani menjadi tidak produktif. Beragam aktivitas bisa dilakukan, khususnya yang bisa menopang kebutuhan pangan rumah tangga. Salah satu yang bisa dilakukan adalah berkebun sayuran organik di pekarangan rumah. Aspek terpenting dalam pemanfaatan halaman rumah ini adalah tanaman hasil dari bertani di halaman rumah dapat mensejahterakan masyarakat baik dari segi penggunaan pribadi ( konsumsi ) maupun untuk produksi ( penjualan ).

Keterbatasan lahan menjadi sebuah tantangan yang dihadapi masyarakat untuk bisa berkebun di lahan terbatas ( halaman rumah ). Berkebun juga merupakan sebuah upaya pemanfaatan ruang minimalis yang terdapat di perkotaan agar dapat 
menghasilkan tanaman yang bermanfaat. Tanaman yang dihasilkan ini pun bisa menjadi alternatif pemenuhan kebutuhan pangan, kenyamanan hidup ditengah polusi udara perkotaan dan dapat menghadirkan nuansa sejuk pada rumah pada masa covid 19 ini.

Hidroponik vertikultur merupakan sebuah alternatif yang sangat sesuai dengan kebutuhan masyarakat kota yang ingin menjalani hobi berkebun dengan pola hidup sehat. Dengan itu, setiap penduduk kota dapat memaksimalkan lahan yang sempit untuk kegiatan berkebun yang dialakukan secara intensif dengan teknologi yang memungkinkan hasil yang maksimal pada lahan terbatas dan bisa sekaligus menghasilkan panganan yang sehat. Hidroponik vertikultur juga diharapkan dapat memenuhi kebutuhan pangan seharihari dengan keuangan yang dapat dijangkau, lalu juga dapat mengurangi pencemaran udara terutama gas $\mathrm{CO} 2$ yang akan diserap oleh tanaman.

Hidroponik vertikultur termasuk dalam kegiatan urban farming atau aktivitas pertanian di dalam atau di sekitar perkotaan yang melibatkan keterampilan, keahlian dan inovasi dalam budidaya dan pengolahan tanaman dan pangan. Hal utama yang menyebabkan munculnya aktivitas ini adalah upaya memberikan kontribusi pada ketahanan pangan, menambah penghasilan masyarakat sekitar juga sebagai sarana rekreasi dan hobi (Wiraraja, 2011).

Walaupun metode hidroponik vertikultur ini sangat sesuai untuk kegiatan berkebun diperkotaan, akan tetapi masih banyak masyarakat yang belum mengetahui informasi tentang metode berkebun. Adapun sebuah komunitas di kota Bandung dengan nama Bandung Berkebun pun sedang menggalakan kegiatan urban farming, namun pada aktivitasnya lebih banyak mengajak masyarakat untuk menanam dengan cara konvensional, dan tentunya itu merupakan sebuah masalah bagi masyarakat yang memiliki lahan terbatas. Ditambah dengan istilah yang terdengar asing dan kurangnya informasi tentang hidroponik vertikultur membuat metode ini tidak begitu diminati.

Perlunya sebuah informasi yang mudah dicerna oleh masyarakat agar dapat membuat berkebun dengan metode hidroponik vertikultur ini bisa menjadi sebuah alternatif baru untuk masyarakat yang memiliki keinginan untuk berkebun. Diharapkan dengan adanya penyebaran informasi yang merata akan berdampak pada masyarakat yang akan semakin produktif, dapat menghasilkan sayuran sehat tanpa pestisida, kualitas hidup yang semakin baik, memperindah halamannya dengan banyaknya tanaman, dan diharapkan dapat menjadi sebuah gaya hidup baru di kawasan perkotaan.

Dari hasil observasi dan wawancara dengan pihak-pihak terkait, dapat diketahui bahwa permasalahan utama petani dalam bertani di halaman rumah yaitu keterbatasan lahan yang ada dan juga jumlah panen yang terbatas serta varietas tanaman yang tidak beragam.

\section{TINJAUAN PUSTAKA}

\section{Profil Kelurahan Tempuling}



Tempuling adalah salah satu kecamatan di Kabupaten Indragiri Hilir, Provinsi Riau yang memiliki luas wilayah $691,19 \mathrm{Km}^{2}$ atau $69,119 \mathrm{Ha}$ yang terdiri dari 4 Kelurahan dan 5 Desa dengan Ibu Kota Kecamatan adalah Sungai Salak, dengan batas wilayah sebagai berikut :

1. Sebelah Utara dengan Kecamatan Batang Tuaka

2. Sebelah Selatan dengan Kecamatan Enok

3. Sebelah Barat dengan Kecamatan Rengat Kabupaten Indragiri Hulu

4. Sebelah Timur dengan Kecamatan Tembilahan

\section{Kelurahan dan desa di kecamatan \\ Tempuling}

1. Kelurahan Sungai Salak

2. Kelurahan Pangkalan Tujuh

3. Kelurahan Tanjung Pidada

4. Kelurahan Tempuling

5. Desa Teluk Jira

6. Desa Mumpa

7. Desa Karya Tunas Jaya

8. Desa Teluk Kiambang

9. Desa Harapan Jaya

\section{Gegrafi Tempuling}

Tinggi pusat pemerintahan Kecamatan Tempuling dari permukaan laut adalah $1 \mathrm{~s} / \mathrm{d}$ 4 meter. Ditepi -tepi sungai dan muara parit -parit banyak terdapat tumbuhan tumbuhan seperti pohon nipah. Keadaan tanahnya sebagian besar terdiri dari tanah 
gambut dan endapan sungai serta rawa rawa. Keadaan tanahnya yang sebagian besar terdiri tanah gambut maka daerah maka daerah ini digolongkan sebagai daerah yang beriklim tropis basah dengan udara agak lembap. Curah hujan tertinggi terjadi pada Bulan April yaitu 348,00 mm dan terendah pada Bulan Oktober yaitu 66,00 $\mathrm{mm}$, sedangkan hari hujan tertinggi terjadi pada Bulan Desember sebanyak 16 hari dan terendah pada Bulan Oktober sebanyak 4 hari.

\section{Pemerintahan}

Dalam upaya meningkatkan
penyelenggaraan pemerintahan,
pelaksanaan pembangunan dan pelayanan
masyarakat secara berdaya guna dan
berhasil guna, pemerintah telah
mengadakan penataan kembali struktur
organisasi pemerintah Kecamatan
berdasarkan Struktur Organisasi pola
minimal sesuai dengan keputusan Gubernur
Provinsi Riau Nomor : 218 Tahun 1997 dan
keputusan Mendagri nomor : 20 Tahun 1997
tentang Tata Kerja Pemerintah Kecamatan.
Dalam menjalankan tugas pokok dan fungsi
Camat tempuling di bantu oleh sekretaris
kecamatan , 5 (lima) kasi pemberdayaan
masyarakat serta beberapa instansi vertikal
yang ada di wilayah Kecamatan Tempuling.

\section{Penduduk}

Jumlah penduduk Kecamatan Tempuling berdasarkan hasil registrasi penduduk akhir tahun yang di laksanakan pada bulan desember 2016 sebanyak 36,844 jiwa dengan kepadatan penduduk 53 jiwa per $\mathrm{Km} 2$. Umumnya penduduk mempunyai pencarian di bidang ppertanian, perkebunan, nelayan perdagangan dan kerajinan industri. Penduduk kecamatan Tempuling terdiri dari berbagai suku antara lain: 1) Banjar 67\%, 2) Melayu $11 \%, 3$ ) Jawa $9 \%, 4$ ) Bugis $8 \%$, 5) Minang $3 \%, 6$ ) Lainnya $2 \%$.

\section{Pertanian Halaman Rumah}

Pekarangan merupakan suatu lahan yang berada di sekitar rumah. Hampir semua rumah memiliki pekarangan. Ibarat sebuah bunga maka putik dan benang sari sebagai rumah sedangkan mahkota sebagai pekarangannya. Fungsi dan keberadaan saling melengkapi. Apabila dikelola dengan baik maka lahan ini dapat memberikan keuntungan bagi pemilik.

Pekarangan berfungsi sebagai pembatas lahan rumah dengan lahan lain baik lahan milik orang lain maupun lahan sendiri yang digunakan untuk keperluan lain (misal kebun). Selain fungsi tersebut, pekarangan mempunyai fungsi estetis maupun ekonomis. Halaman berfungsi estetis karena biasanya pekarangan diberi atau ditanami dengan penghias rumah seperti dekorasi atau tanaman bunga sehingga rumah kelihatan lebih indah dan asri. Nilai ekonomis berkaitan dengan kemampuan lahan pekarangan untuk menghasilkan tambahan pendapatan bagi pemilik misal dengan ditanami tanaman hortikultura (buah dan sayuran) dan budidaya ternak, unggas atau ikan. Pemanfaatan pekarangan yang baik dapat mendatangkan berbagai manfaat antara lain yaitu sebagai warung, apotek ,lumbung hidup dan bank hidup (Ashari dkk 2012). Disebut lumbung hidup karena sewaktu-waktu kebutuhan pangan pokok seperti jagung, umbiumbian dan sebagainya tersedia di pekarangan.Selain pekarangan difungsikan untuk pemenuhan bahan pangan (Arifin dkk. 2007), pekarangan untuk konservasi keanekaragaman hayati pertanian dapat juga mendukung agroekologi dan pertanian yang keberlanjutan (Marshall dan Moonen 2002).

Luas pekarangan yang umumnya sempit menjadikan lahan ini kurang dilirik untuk diusahakan secara komersial dan besarbesaran. Hanya beberapa kalangan yang melihat potensi lahan ini dengan memanfaatkan teknologi budidaya mengingat keterbatasan luas lahan. Namun demikian lahan pekarangan mempunyai beberapa kelebihan dibandingkan dengan jenis lahan lain. Kelebihan tersebut antara lain berkaitan dengan jarak yang dekat dengan rumah (pemilik) sehingga mudah diawasi dan dikelola. Selain itu ketersediaan air lebih dekat dengan sumber sehingga kebutuhan air dapat terpenuhi.

Potensi yang selama ini sudah dimanfaatkan dan masih berpeluang besar untuk dikembangkan adalah dengan menjadikan pekarangan sebagai salah satu lahan pertanian mini yang dapat dimanfaatkan untuk memenuhi kebutuhan rumah tangga (keluarga) itu sendiri. Pengaturan areal pertanaman tergantung pada kondisi pekarangan. Areal bisa dipilih di depan, belakang, samping rumah atau kombinasi.

Budidaya pekarangan tidak hanya dilakukan secara monokultur (satu jenis komoditas) namun bisa pula secara polikultur (beragam jenis komoditas). Pilihan tersebut disesuaikan dengan kemampuan dan keterampilan suatu keluarga.

\section{Keaneka ragaman tanaman yang menguntungkan untuk pertanian halaman rumah}




\section{a. Tanaman Sayuran}

Lahan pekarangan yang kosong dapat ditanami dengan berbagai komoditas pertanian. Komoditas hortikultur yang umum ditanam di pekarangan adalah berbagai macam sayuran. Jenis sayuran yang dapat ditanam adalah sayuran kangkung, bayam, selada, cabai, sawi dan lain-lain. Hasil panen sayuran diutamakan untuk memenuhi kebutuhan keluarga dulu. Apabila ada lebih maka bisa dijual sehingga pendapatan keluarga bertambah.

\section{b. Tanaman Pagar}

Tanaman pagar disebut juga pagar hidup, maksudnya pagar yang sengaja dibuat dari tanaman. Tanaman pagar dipilih dari jenis yang dapat dimanfaatkan oleh pemilik. Beberapa tanaman yang sering dijadikan sebagai pagar adalah tanaman mangkokan, puring, petai cina, singkong, puring dan lain-lain. Bagian tanaman ini bisa dimanfaatkan sebagai sayuran, obat-obatan maupun bahan bangunan. Selain bisa pemilik bisa memperoleh pendapatan, tanaman ini bisa juga dijadikan penghias rumah yang indah.

\section{c. Tanaman Buah}

Tanaman buahan merupakan salah satu tanaman yang umum ditanam di lahan pekarangan. Tanaman ini dimaksudkan sebagai penghasil buah yang akan dikonsumsi untuk keluarga maupun untuk tujuan komersial. Tanaman buah yang tingg dan rindang biasanya juga dimaksudkan sebagai peneduh dan pelindung rumah dari cahaya matahari. Buah-buahan yang umum ditanam adalah jambu, jeruk, rambutan, pisang, mangga, strawberi dan lain-lain.

\section{d. Tanaman Obat dan bumbu dapur} Masa kini, paradigma masyarakat berubah menjadi back to nature atau kembali ke alam. Lahgan pekarangan juga bisa dimanfaatkan untuk ditanami tanaman obat. Tanaman ini sangat bermanfaat untuk pengobatan tradisional dan sebagai salah satu bumbu dapur. Tanaman obat yang bisa ditanam di sekitar rumah adalah kunyit, sereh, kencur, mahkota dewa, tapak dara, kumis kucing dan lain-lain.

\section{f. Bunga}

Bunga ditanam untuk mempercantik pekarangan rumah. Apabila rumah terlihat asri dan nyaman maka anggota keluarga pun akan memperoleh manfaat secara rohani.

\section{Ragam Metode tanam pertanian lahan sempit di halaman rumah}

\section{a. Tabulampot}

Pengertian tabulampot adalah pembudidayaan yang menggambarkan suatu aktifitas tanam menanam buah yang dapat dilakukan pada media pot, sebenarnya tidak harus dengan media pot saja kita juga dapat menanam tabulampot, apabila dengan menggunakan pot identik kita harus dapat mengeluarkan biaya untuk membelinya, tetapi seperti yang telah dijelaskan pada paragraf di atas, bagi mereka yang lebih kreatif, inovatif, serta telaten maka mereka akan memaksimalkan limbah yang bisa dimanfaatkan sebagi media menanam di tabulampot dan tentunya akan sangat mengurangi biaya yang kita keluarkan dan menanam atau budidaya tabulampot.

Kelebihan atau

tabulampot sebagai berikut :

1. Kita dapat memaksimalkan lahan yang sempit untuk dapat menyalurkan hobi dalam budidaya tanaman buah.

2. Perawatan lebih terjamin, perawatan pada tabulampot diantaranya kita bisa lebih maksimal dalam pemenuhan nutrisi atau pemupukan tanaman, serangan hama serta penyakit lebih mudah kita kontrol, kebutuhan air tanaman bisa tercukupi karena tanaman mudah kita pantau perkembangan tanamannya, pemangkasan cabang tanaman untuk bisa mendapatkan vigor tanaman yang baik menjadi lebih mudah.

3. Dapat dinikmati dari hasil panennya baik untuk buah yang dikonsumsi sendiri atau menjadi pendapatan tambahan dari hasil buah yang dapat dijual.

\section{b. Vertikultur}

Vertikultur, pada dasarnya merupakan cara bertanam, yang dilakukan dengan menempatkan media tanam dalam wadahwadah yang disusun secara vertikal. Wadah media tanam tersebut dapat berupa kaleng bekas maupun benda-benda bekas yang kemudian di atur sedemikian rupa sehingga pertanaman nantinya dapat tumbuh secara susun ke atas. Sehingga dengan demikian vertikultur merupakan upaya pemanfaatan ruang ke arah vertikal (Nitisapto, 1993). Dari satu titik dengan luasan tertentu dapat ditanam beberapa tanaman. Dengan 
demikian, vertikultur dapat diterapka pada daerah-daerah dengan lahan sempit, khususnya di daerah perkotaan yang kini rata-rata menjadi pemukiman padat penduduk (Ashari, 1995).

Dalam pola tanam vertikultur, air hanya dibutuhkan bagi penguapan (transpirasi) tanaman, mengingat evaporasi hanya terjadi dari dari tanah dalam kolom wadah media tanam. Setiap kali dilakukan penyiraman, beberapa tanaman dapat memperoleh air dari air atusan (tetesan) tanaman di atasnya. Dengan demikian, dirasakan pola vertikultur ini dapat lebih menghemat penggunaan air (Sutarminingsih, 2003).

Vertikultur juga dapat dilakukan pada daerah-daerah dengan kondisi lahan yang kurang subur, dengan syarat media tanamnya diupayakan dapat mendukung pertumbuhan tanaman, misalnya dengan mencari media tanah dari lokasi lain, menambahkan pupuk atau hara, dan lain sebagainya. Pada prinsipnya, vertikultur dapat dilakukan seperti menanam tanaman dalam pot yang tidak tergantung pada kondisi lahan setempat dan iklim suatu wilayah (Sutarminingsih, 2003).

Penerapan pola tanam vertikultur, mempunyai beberapa keunggulan, antara lain sebagai berikut :

1. Menghemat lahan.

2. Menghemat air.

3. Mendukung Pertanian organik, karena lebih menganjurkan penggunaan pupuk alami dan sedikit mungkin menggunakan pestisida anorganik.

4. Bahan-bahan yang digunakan sebagai wadah media tanam, dapat disesuaikan dengan kondisi setempat atau ketersediaan bahan yang ada.

5. Umur tanaman relatif pendek.

6. Pemeliharaan tanaman relatif sederhana ( Desiliyarni, 2003).

\section{c. Hidroponik}

Hidroponik dalam arti yang luas adalah teknik bercocok tanam tanpa menggunakan tanah sebagai media tanamnya. Dimana prinsip dasar penerapan budidaya tanaman secara hidroponik adalah memberikan atau menyediakan nutrisi yang diperlukan tanaman dalam bentuk larutan dengan cara disiramkan, diteteskan, dialirkan atau disemprotkan pada media tumbuh tanaman.

Hidroponik memiliki beberapa keunggulan sebagai berikut :
- Tingkat keberhasilan tanaman untuk tumbuh dan berproduksi lebih terjamin.

- Dapat dilakukan dimana saja tidak tergantung sifat fisik dan kimia tanah, dan dapat dilakukan pada lahan yang sempit ataupun gersang.

- Produktivitas tanaman lebih tinggi serta lebih kontinu.

- Perawatan terhadap gangguan hama dan penyakit lebih terkontrol serta lebih praktis

- Pertumbuhan tanaman lebih cepat

- Kualitas hasil produknya lebih baik (bersih dan tidak rusak)

- Penggunaan pupuk lebih hemat (efisien)

- Efisiensi tenaga kasar (misalnya mencangkol, membajak, dan lain-lain)

- Beberapa jenis tanaman dapat ditanam diluar musimnya.

- Tidak ada risiko kebanjiran, erosi, kekeringan atau ketergantungan pada kondisi alam

- Harga jual relatif lebih tinggi

\section{d. Aeroponik}

Istilah aeroponik berasal dari dua kata, yaitu aeros yang memiliki arti udara dan ponus berarti daya. Kedua istilah ini merupakan bahasa Yunani. Mengacu pada kedua istilah di atas, aeroponik memiliki arti memberdayakan sesuatu dengan memanfaatkan udara.

Pengertian lengkap dari aeroponik adalah sistem budi daya tanaman yang tidak menggunakan tanah sebagai media tanam, melainkan menggunakan media tanam berupa udara. berikut :

$$
\text { Keunggulan Aeroponik sebagai }
$$

1. Sistem aeroponik membantu lingkungan dengan menghemat air,

2. mengurangi jumlah tenaga kerja manusia yang terlibat.

3. Karena akar di udara, tanaman menerima lebih banyak oksigen.

4. Oksigen tambahan yang tanaman terima dapat meringankan pertumbuhan patogen berbahaya.

5. Teknik aeroponik membantu lingkungan dengan menghemat air mengurangi jumlah tenaga kerja manusia yang terlibat, dan biasanya $100 \%$ aman.

6. Tanaman dapat memanfaatkan karbon-dioksida yang kaya oksigen di udara untuk melakukan fotosintesis.

7. Menggunakan, tertutup tanahkurang lingkungan sangat mengurangi (atau menghilangkan dengan total tertutup sistem) ancaman terhadap tanaman seperti penyakit dan hama. 


\section{Pemasaran Pertanian}

\subsection{Pengertian Pemasaran}

Pemasaran secara umum dapat diartikan sebagai suatu kegiatan atau jasa yang dilakukan untuk memindahkan atau memproduksi suatu barang atau jasa dari produsen ke konsumen. Sedangkan pengertian pemasaran menurut para ahli adalah :

- Menurut G. Karta Sapoetro,cs.

Pemasaran adalah Segala yang dilakukan agar barang - barang hasil produksi dari produsen dimungkinkan mengalir secara lancer ke sektor konsumen.

- Menurut Philip dan Duncan

Pemasaran meliputi semua langkah yang dipergunakan untuk menempatkan barangbarang nyata ketangan konsumen.

- $\quad$ Menurut W.J. Stanton

Pemasaran meliputi keseluruhan sistem yang berhubungan dengan kegiatankegiatan usaha, yang bertujuan merencanakan, menentukan harga, hingga mempromosikan, dan mendistribusikan barang-barang atau jasa yang akan memuaskan kebutuhan pembeli, baik yang actual maupun yang potensial.

- Menurut Kotler

Pemasaran adalah Proses sosial dan manajerial dimana individu dan kelompok mendapatkan kebutuhan mereka dengan menciptakan, menawarkan dan bertukar produk yang bernilai satu sama lain.

- Menurut American Marketing Association

Pemasaran pelaksanaan kegiatan usaha niaga yang diarahkan pada arus aliran barang dan jasa dari produsen kekonsumen.

\subsection{Fungsi Pemasaran}

Dalam proses pengaliran barang dari produsen ke konsumen diperlukan aktivitas, tindakan atau perlakuan-perlakuan untuk memperlancar perpindahan hak milik barang yang diistilahkan sebagai fungsi pemasaran.

Fungsi pemasaran adalah kegiatan utama yang khusus dilaksanakan untuk menyelesaikan proses pemasaran. Beberapa fungsi penting dalam pemasaran hasil pertanian antara lain fungsi penyimpanan, transportasi, grading dan standardisasi, serta periklanan.

1. Fungsi penyimpanan dimaksudkan untuk menyeimbangkan periode panen dan periode paceklik. Ada empat alasan pentingnya penyimpanan untuk produkproduk pertanian, yaitu:

a) Produk bersifat musiman

b) Adanya permintaan akan produk pertanian yang berbeda sepanjang tahun,

c) Perlunya waktu untuk menyalurkan produk dari produsen ke konsumen,

d) Perlunya stok persediaan untuk musim berikutnya.

2. Fungsi transportasi dimaksudkan untuk menjadikan suatu produk berguna dengan memindahkannya dari produsen ke konsumen. Biaya transportasi ditentukan oleh:

a) Lokasi produksi,

b) Area pasar yang dilayani,

c) Bentuk produk yang dipasarkan,

d) Ukuran dan kualitas produk yang dipasarkan.

Fungsi standardisasi dan grading dimaksudkan untuk menyeder-hanakan dan mempermudah serta meringankan biaya pemindahan komoditi melalui saluran pemasaran.

3. Grading adalah penyortiran produkproduk ke dalam satuan atau unit tertentu. Standardisasi adalah justifikasi kualitas yang seragam antara pembeli dan penjual, antar tempat dan antar waktu. Manfaat standardisasi dan grading dalam pemasaran:

a) Mempermudah pembeli dan produsen memberikan nilai barang tersebut

b) Mempermudah proses jual beli

c) Mengurangi biaya pemasaran dan menekan resiko dalam pengangkutan

d) Memperluas pasaran, sesuai dengan kualitas yang diinginkan dan kemampuan konsumen.

e) Syarat mutlak untuk pemasaran berjangka (future market)

4. Fungsi periklanan dimaksudkan untuk menginformasikan ke konsumen apa yang tersedia untuk dibeli dan untuk mengubah permintaan atas suatu produk. Masalah yang timbul dalam periklanan produk-produk pertanian terutama berkaitan dengan karakteristik produkproduk pertanian itu sendiri. Maksud produsen terhadap tampilan produk yang dipublikasikan melalui periklanan, antara lain:

a) Memperkenalkan identitas produk yang diinformasikan dan menjelaskan perbedaan produk dengan yang lain.

b) Mengkomunikasikan konsep produk, yaitu manfaat dan kelebihannya dari segi fungsional, psikologis, atau nilai pasar sasaran. 
c) Mengarahkan pemakaian produk baik yang lama atau yang baru kepada pasar sasaran.

d) Memberitahukan tempat penjualan atau pembelian untuk merangsang ditribusi yang lebih luas.

e) Meningkatkan penjualan yang berarti pula produk meningkat.

f) Membangun citra produk dan menjaga kemampuan posisi produk dalam pandangan pasar sasaran

g) Menghadapi dan mengatasi masalah saingan antar produk.

\subsection{Saluran Pemasaran}

Saluran pemasaran merupakan suatu jalur yang dilalui oleh arus barang-barang dari produsen ke perantara dan akhirnya sampai ke konsumen. Pada pemasaran komoditas pertanian sering dijumpai adanya rantai pemasaran yang panjang yang melibatkan banyak pelaku pemasaran. Hanafiah dan Saefuddin (1986), menyatakan bahwa panjang pendeknya saluran pemasaran yang dilalui tergantung dari beberapa faktor, yaitu jarak antara produsen dan konsumen, cepat tidaknya produk rusak, skala produksi, dan posisi keuangan pengusaha.

Kotler

(1991)

panjangnya saluran membagi saluran beberapa tingkatan, yaitu:

\section{a. Saluran nol tingkat}

Saluran ini disebut pula saluran pemasaran langsung yang terdiri dari seorang produsen yang menjual langsung kepada konsumen. Tiga cara penting dalam saluran ini adalah penjualan dari rumah ke rumah, penjualan lewat pos, dan penjualan lewat toko perusahaan.

\section{b. Saluran satu tingkat}

Saluran ini mempunyai satu perantara penjualan. Pada pasar konsumen, perantara sekaligus merupakan pengecer.

\section{c. Saluran dua tingkat}

Saluran ini mempunyai dua perantara. Pada pasar konsumen, grosir atau pedagang besar sekaligus sebagai pengecer.

\section{d. Saluran tiga tingkat}

Saluran ini mempunyai tiga perantara, misalnya dalam industri pengalengan buah. Dalam industri ini, seorang pemborong biasanya berada di tengah antara grosir dan pengecer. Pemborong membeli dari grosir dan menjual ke pengecer kecil yang biasanya tidak dilayani oleh pedagang kelas kakap.

\subsection{Marjin Pemasaran}

Marjin pemasaran adalah perbedaan harga di antara tingkat lembaga dalam sistem pemasaran atau perbedaan antara jumlah yang dibayar konsumen dan jumlah yang diterima produsen atas produk pertanian yang diperjualbelikan. Selain secara verbal, marjin pemasaran dapat dinyatakan secara matematis dan secara grafis.Produk referensi merupakan titik awal yang menunjukkan 1 kilogram dari produk yang dijual kepada konsumen, misalnya petani perlu menyediakan 1,11 kilogram tomat untuk menyediakan 1 kilogram dari produk referensi karena 10 persen dari produk yang dijual telah hilang/rusak dalam proses pemasaran.

Ada tiga metode untuk menghitung marjin pemasaran yaitu dengan memilih dan mengikuti saluran pemasaran dari komoditi spesifik, membandingkan harga pada berbagai level pemasaran yang berbeda, dan mengumpulkan data penjualan dan pembelian kotor tiap jenis pedagang. Masing-masing metode memiliki kelemahan dan kelebihan.Marjin pemasaran menurut jenisnya dibedakan menjadi marjin absolut, persen marjin dan kombinasi antara marjin absolut dan persen marjin.Persentase bagian marjin merupakan suatu pengelompokan yang digunakan secara populer pada serangkaian angka yang menunjukkan marjin absolut dari berbagai tipe pedagang atau berbagai fungsi pemasaran yang berbeda, dibagi dengan harga eceran.

Komponen biaya pemasaran berdasarkan berbagai kegiatan pemasaran yang umumnya dilakukan meliputi biaya persiapan dan pengepakan, biaya handling, biaya processing, biaya modal, pungutanpungutan, komisi dan pembayaran tidak resmi.

\subsection{Peran Lembaga Pemasaran \\ Masing-masing}

Lembaga pemasaran adalah badan usaha atau individu yang menyelenggarakan pemasaran, menyalurkan jasa dan komoditi dari produsen ke konsumen akhir, serta mempunyai hubungan dengan badan usaha atau individu lainnya. Lembaga pemasaran muncul karena adanya keinginan konsumen untuk memperoleh komoditi yang sesuai dengan waktu (time utility), tempat (place utility), dan bentuk (form utility). 
Lembaga pemasaran bertugas untuk menjalankan fungsi-fungsi pemasaran serta memenuhi keinginan konsumen semaksimal mungkin. Imbalan yang diterima lembaga pemasaran dari pelaksanaan fungsi-fungsi pemasaran adalah margin pemasaran (yang terdiri dari biaya pemasaran dan keuntungan). Bahagian balas jasa bagi lembaga pemasaran adalah keuntungan yang diperoleh dari kegiatan pemasaran.

\section{Golongan lembaga pemasaran:}

1. Menurut penguasaannya terhadap komoditi yang diperjual belikan, lembaga pemasaran dapat dibedakan menjadi 3 (tiga) yaitu:

- Lembaga yang tidak memiliki komoditi, tetapi menguasai komoditi, seperti agen dan perantara, makelar (broker, selling broker, dan buying broker) Lembaga yang memiliki dan menguasai komoditikomoditi yang dipasarkan, seperti: pedagang pengumpul, tengkulak, eksportir, dan importir.

- Lembaga pemasaran yang tidak memiliki dan menguasai komoditi yang dipasarkan, seperti perusahaanperusahaan yang menyediakan fasilitas transportasi, auransi pemsaran, dan perusahaan yang menentukan kualitas produk pertanian (surveyor).

2. Berdasarkan keterlibatan dalam proses pemasaran, yaitu:

- Tengkulak, yaitu lembaga pemasaran yang secara langsung berhubungan dengan petani. Tengkulak melakukan transaksi dengan petani baik secara tunai, ijon maupun kontrak pembelian.

- Pedagang pengumpul, yaitu lembaga pemasaran yang menjual komoditi yang dibeli dari beberapa tengkulak dari petani. Peranan pedagang pengumpul adalah mengumpulkan komoditi yang dibeli tengkulak dari petani-petani, yang bertujuan untuk meningkatkan efisiensi pemasaran seperti pengangkutan.

- Pedagang besar, untuk lebih meningkatkan pelaksanaan fungsifungsi pemasaran maka jumlah komoditi yang ada pada pedagang pengumpul perlu dikonsentrasikan lagi oleh lembaga pemasaran yang disebut pedagang besar. Pedagang besar juga melaksanakan fungsi distribusi komoditi kepada agen dan pedagang pengecer.

- Agen penjual, bertugas dalam proses distribusi komoditi yang dipasarkan, dengan membeli komoditi dari pedagang besar dalam jumlah besar dengan harga yang realtif lebih murah.

- Pengecer (retailers), merupakan lembaga pemasaran yang berhadapan langsung dengan konsumen. Pengecer merupakan ujung tombak dari suatu proses produksi yang bersifat komersil. Artinya kelanjutan proses produksi yang dilakukan oleh produsen dan lemabagalembaga pemasaran sangat tergantung dengan aktivitas pengecer dalam menjual produk ke konsumen. Oleh sebab itu tidak jarang suatu perusahaan menguasai proses produksi sampai ke pengecer.

Seluruh lembaga-lembaga pemasaran tersebut dalam proses penyampaian produk dari produsen ke konsumen berhubungan satu sama lain yang membentuk jaringan pemasaran. Arus pemasaran (saluran pemasaran) yang terbentuk dalam proses pemasaran ini beragam sekali, misalnya:

- $\quad$ Produsen berhubungan langsung dengan konsumen akhir

- $\quad$ Produsen - tengkulak - pedagang pengumpul - pedagang besar - pengecer konsumen akhir

- $\quad$ Produsen - tengkulak - pedagang besar - pengecer - konsumen akhir

- $\quad$ Produsen - pedagang pengumpul pedagang besar - pengecer - konsumen akhir, dll

Hubungan antar lembaga-lembaga tersebut akan membentuk pola-pola pemasaran yang khusus. Pola pemasaran yang terbentuk selama pergerakan arus komoditi pertanian dari petani ke konsumen akhir disebut sistem pemasaran.

Peran/fungsi Lembaga Pemasaran:

\section{Pengecer (Retailer)}

Fungsi-fungsi pemasaran yang dilaksanakan adalah:

- mengkombinasikan beberapa jenis barang tertentu

- melaksanakan jasa-jasa eceran untuk barang tersebut

- menempatkan diri sebagai sumber barang-barang bagi konsumen

- menciptakan keseimbangan antara harga dan kualitas barang yang di perdagangkan

- menyediakan barang-barang untuk memenuhi kebutuhan konsumen

- melaksanakan tindakan-tindakan dalam persaingan

Klasifikasi pedagang pengecer: 
a. berdasarkan luasnya product line (jenis produk), terdiri dari:

- Speciality store, yaitu pengecer yang menjual hanya satu macam produk. Misalnya toko pakaian anak-anak, pakaian wanita, dll.

- Toko Serba Ada (TOSERBA) atau department store, yaitu golongan pengecer yang menjual berbagai macam product line. Biasanya toserba memiliki volume usaha yang besar, kondisi keuangan kuat, dan beroperasi sebagai perusahaan,

- Single line store, yaitu pengecer yang hanya menjual satu macam product line, seperti toko buah, toko makanan, toko bangunan, dll.

b. berdasarkan bentuk pemilikan, terdiri atas:

independent store, yaitu kepemilikan perorangan, yang sekaligus berfungsi sebagai pimpinan,

- Corporate chain store, yaitu beberapa toko yang berada dibawah satu organisasi, dan dimiliki oleh sekelompok orang. Masing-masing toko menjual product line yang sama dan struktur distribusinya juga sama.

c. berdasarkan penggunaan fasilitas, dibedakan atas:

- Store retailer atau toko pengecer, yaitu pengecer yang memiliki toko sendiri, atau tempat menjual barang-barang,

- Non store retailer atau pengecer tanpa toko, yaitu pengecer yang menjual produknya dengan menggunakan fasilitas lain, seperti: menjajakan produk dari rumah ke rumah, penjualan melalui pos, penjualan melalui internet, penjualan melalui mesin otomatis, dll.

$$
\begin{aligned}
& \text { d. berdasarkan ukuran toko, } \\
& \text { dibedakan atas: }
\end{aligned}
$$

- Pengecer kecil (small scale retailer)

- Pengecer besar (large scale retailer)

\section{Pedagang besar (wholesaler)}

Menurut fungsi yang dilakukan pedagang besar dapat digolongkan menjadi:

a. Pedagang besar dengan fungsi penuh (full function wholesaler), yaitu: pedagang besar yang melaksanakan fungsi-fungsi pemasaran secara keseluruhan, mulai dari: fungsi pembelian - penjualan - pengangkutan - penyimpanan - fungsi keuangan - fungsi pengambilan resiko, dll. Dalam menjalankan aktivitasnya pedagang besar dalam ketegori ini biasanya selalu menjaga persediaan yang cukup dan lengkap, menggunakan beberapa penjual (salesman), dan melakukan hubunganhubungan secara teratur dengan pengecer.

b. Pedangan besar dengan fungsi terbatas (limited function wholesaler), yaitu: pedagang besar yang hanya menjalankan fungsi atau jasa yang terbatas. Dasar pertimbangan meninggalkan fungsi lain adalah untuk efisiensi dan mengurangi resiko dalam pemsaran. Dalam hal ini fungsi-fungsi tersebut terbagi pada produsen, dan pedagangn pengecer. Pedagangan besar yang masuk dalam golongan fungsi terbatas adalah:

- Mail order wholesaler, yaitu: pedagang besar yang melakukan penyaluran barang secara sentral, melalui pos, tanpa menggunakan penjual.

- Chas and carry wholesaler, yaitu: pedagang besar yang melakukan perdagangan secara tunai, dan tidak melakukan penghantaran barang (non delivery order), bisanya jumlah barangbarangnya terbatas.

- Drop shipper, yaitu: pedagang besar yang tidak melakukan penyimpanan, kegiatan yang dilakukan biasanya melalui telepon, sehingga menghemat biaya eksploitasi (biaya eksploitase rendah),

- Raak Jobber, yaitu: pedangan besar yang khusus memberikan jasa dan mengatur barang-barang miliknya di toko pengecer,

- Wagon Jobber, yaitu pedagang besar yang khusus melayani perdagangan barang-barang secara cepat, terutama barang yang mudah rusak dan busuk.

\section{Agen Penunjang (Facilitating Agent)}

Agen merupakan salah satu perantara yang penting dalam saluran distribusi, karena dapat membantu dalam pelaksanaan fungsi pemasaran secara baik dan lebih efisien, karena agen membantu pedagang dalam memindahkan produk.

$$
\text { Agen penunjang dapat }
$$
dikategorikan berdsarkan fungsi yang dilakuan, yaitu:

a. Agen pembelian dan penjualan (purchasing and sales agent), yaitu: lembaga pemasaran yang bekerja 
atas kontrak tertentu untuk melakukan pembelian barang, dengan menerima sejumlah komisi atas penggunaan jasa pembelian, tidak berhak atas barang yang dibeli atau dijual, dan tidak dapat bertindak menyaingi pedagang yang pengontrak. Jenis-jenis agen pembelian dan penjualan adalah:

- Free lance broker (makelar), yaitu: pelaku pemasaran yang tidak memiliki daerah yang tetap, dan dapat merundingkan penjualan untuk siapapun, tidak ada batasan wilayah, terikat masalah harga, syarat, dan kondisi penjualan dengan pengontrak.

- Agen pabrik (manufacturer's agent), yaitu: agen yang mengadakan perundingan untuk menjual barangbarnag dari pengontraknya. Agen pabrik mempunyai ikatan dengan pengontrak dalam hal wilayah, harga, syarat, dan kondisi penjualan.

- $\quad$ Agen penjual (sales agent), yaitu: agen yang dikontrak oleh perusahaan untuk menjualkan produk perusahaan dalam wilayah yang tidak terbatas.

- Agen pembelian (purchasing agent), yaitu: agen yang bertindak sebagai pembeli (kadang disebut pembeli tetap), dan mencari sumber-sumber persediaan (supply) untuk beberapa pedagang pengontrak. Biasaya dilakukan oleh chain store dan toko serba ada.

b. Agen pengangkutan, terdiri dari dua kategori, yaitu: 1) bulk transportation agencies (agen pengangkut borongan), dan 2) specialty shippers (agen pengangkutan khusus).

c. Agen penyimpanan (storage agent), terdiri dari: 1) pedagang komisi, 2) gudang umum (public warehouse)

d. Franchise, yaitu: seorang penjual memberikan hak kepada seorang pembeli untuk memasarkan barang-barangnya, tetapi pembeli harus bersedia mengikuti kebijaksanaan yang ditetapkan oleh penjual dan tidak menjual barang-barang saingan. Dalam franchising biasanya terdapat adanya kerjasama mengenai soal harga, periklanan, dan kebijaksanaan-kebijaksanaan lainnya. Franchising ada 2 bentuk, yaitu 1) product franchising, yaitu: kerjasama penjualan barang secara individual, missal pengecer yang menjual bermacam-macam barang tetapi bukan barang saingan, dan 2) business franchising yaitu: meningkatkan kerjasama dan komunikasi dalam saluran.

\section{METODOLOGI PENELITIAN}

\section{a. Jenis Penelitian}

Jenis penelitian yang digunakan adalah penelitan diskriptif kualitatif,. Penelitian yang dilakukan oleh penulis menggunakan metode wawancara dan Diskusi. Berdasarkan metode ini diharapkan penulis dapat mengetahui permasalahan masyarakat pada Upaya pemanfaatan halaman rumah sebagai lahan pertanian tanaman budidaya untuk kebutuhan konsumsi dan pemasaran masyarakat pada masa covid 19 di kelurahan tempuling.

\section{b. Waktu dan Tempat Penelitian}

Penelitian yang berjudul "Upaya pemanfaatan halaman rumah sebagai lahan pertanian tanaman budidaya untuk kebutuhan konsumsi dan pemasaran masyarakat pada masa covid 19 di kelurahan tempuling". Waktu penelitian dilakukan pada bulan AgustusSeptember 2020 dalam rentan waktu selama 45 Hari.

\section{c. Populasi dan Sampel}

1. Populasi

Menurut Hadari Nawawi (1983), Populasi adalah keseluruhan objek penelitian yang terdiri atas manusia, hewan, bendabenda, tumbuh, peristiwa, gejala, ataupun nilai tes sebagai sumber data yang mempunyai karakteristik tertentu dalam suatu penelitian yang dilakukan. Oleh karena itu yang dijadikan populasi dalam penelitian ini adalah sebagian masyarakat kelurahan Tempuling.

\section{Sampel}

sampel adalah sebagian dari subyek dalam populasi yang diteliti, yang sudah tentu mampu secara representative dapat mewakili populasinya (Sabar,2007). Sampel yang baik, yang kesimpulannya dapat dikenakan pada populasi, adalah sampel yang bersifat representatif atau yang dapat menggambarkan karakteristik populasi. Yang dijadikan sampel dalam penelitian ini sebanyak 5 orang dari populasi dan penetepan ini diambil berdasarkan metode bailey (survey) merupakan satu metode penelitian yang tekhnik pengambilan datanya dilakukan melalui pertanyaan tertulis ataupun lisan.

\begin{tabular}{|l|l|l|l|}
\hline NO & Nama & Status & Umur \\
\hline
\end{tabular}






\section{Teknik pengumpulan data}

1. Wawancara dilakukan dengan cara tanya jawab dengan responden atau informan untuk memperoleh informasi yang dibutuhkan untuk penelitian. Wawancara digunakan untuk menggali informasi atau persepsi subjektif dari informan terkait topik yang ingin diteliti. Peneliti sebelumnya harus menyiapkan pertanyaan-pertanyaan wawancara terlebih dahulu.

2. Diskusi adalah visi dari dua atau lebih individu yang berinteraksi secara verbal dan dengan saling bertatap muka tentang tujuan atau target yang telah diberikan dengan cara pertukaran informasi (Hasibuan, 1985).

3. Studi kepustakaan (library research) yaitu segala usaha yang dilakukan oleh peneliti untuk menghimpun segala informasi yang relevan dengan topik atau masalah yang akan atau sedang di teliti. Informasi itu dapat di peroleh dari buku-buku ilmiah,laporan penelitian, karangankarangan ilmiah, tesis dan disertasi, peraturan-peraturan, ketetapanketetapan, buku tahunan dan sumber-sumber tertulis baik tercetak maupun elektronik lain.

\section{HASIL DAN PEMBAHASAN}

\section{Alternatif pemecahan masalah}

a. Kebijakan

Masyarakat serta petani harus berinisiatif untuk memutus rantai covid 19 dengan melakukan aktifitas bertani di halaman rumah dan mencoba inovasi atau metode langkah baru untuk bertani. b. Strategi

Memberikan edukasi atau alternatif kepada masyarakat serta petani untuk bertani di halaman rumah dengan berbagai macam metode sebagai alternatif bertani pada masa covid 19

c. Upaya

Berharap agar alternatif bertani di halaman rumah dan metode yang dapat di terapkan mampu membuat masyarakat mendapatkan keuntungan baik sebagai konsumsi maupun penjualan pada masa covid 19 .

\section{Subjek}

Adapun subjek dari penelitian ini adalah para petani serta masyarakat yang ada di kelurahan Tempuling kecamatan Tempuling kabupaten Indragiri Hilir.

\section{Objek}

Yang menjadi objek penelitian ini adalah bagaimana cara petani dan masyarakat umum di kelurahan Tempuling mampu untuk memiliki hasil pangan karena pandemi covid-19 yang membuat masyarakat kurang melakukan aktifitas seperti biasanya dan mampu memiliki hasil dari bertani di halaman rumah sendiri baik untuk konsumsi maupun penjualan.

\begin{tabular}{|l|l|l|}
\hline \multicolumn{1}{|c|}{ SUBJEK } & \multicolumn{1}{|c|}{ METODE } & \multicolumn{1}{c|}{ OBJEK } \\
\hline $\begin{array}{l}\text { 1. Petani } \\
\text { 2. Masyaraka } \\
\mathrm{t}\end{array}$ & $\begin{array}{l}\text { 1. Wawancara } \\
\text { 2. Diskusi }\end{array}$ & KELURAHAN \\
TEMPULING \\
\hline
\end{tabular}

\section{Metode}

Wawancara dan Diskusi mengenai Upaya pemanfaatan halaman rumah sebagai lahan pertanian tanaman budidaya untuk kebutuhan konsumsi dan pemasaran masyarakat pada masa covid 19 di kelurahan tempuling.

Subjek : Petani dan Masyarakat Tempuling

Metode : Wawancara dan Diskusi mengenai Upaya pemanfaatan halaman rumah sebagai lahan pertanian tanaman budidaya untuk kebutuhan konsumsi dan pemasaran masyarakat pada masa covid 19 di kelurahan tempuling 
Objek : Pemanfaatan halaman rumah di kelurahan tempuling

\section{KESIMPULAN DAN SARAN}

Pertanian halaman rumah sangat berpotensi sebagai penunjang atau pengganti pertanian di lahan pada masa covid 19 ini yang mana segala aktifitas di luar rumah sangat harus di batasi oleh pemerintah guna memutus mata rantai covid 19. Budidaya ini dilakukan dalam skala kecil dan diutamakan untuk memenuhi kebutuhan rumah tangga. Beberapa metode yang dapat di lakukan bertani di halaman maupun perkarangan rumah yaitu Tabulampot, vertikultur, hidroponik, serta aeroponik.

Produksi sendiri akan mengurangi pengeluaran rumah tangga sehingga dana yang sebelumnya ditujukan untuk kebutuhan sayur atau buah dapat dialihkan untuk memenuhi kebutuhan lain atau ditabung. Apabila ada kelebihan maka hasil panen bisa dijual. Bahkan bila budidaya di pekarangan ini berhasil maka bisa dikembangkan lebih lanjut untuk tujuan komersial.

Pemasaran merupakan ujung tombak dari tatanan usaha tani, dimana kegiatan dari budidaya dan produksi ditentukan oleh permintaan pasar (konsumen).

\section{Saran}

Untuk Pengembangan lebih lanjut di perlukan tingkat keperdulian masyarakat dan petani akan pentingnya pekarangan rumah sebagai tempat untuk bertani dengan berbagai metode sehingga dapat mencukupi kebutuhan konsumsi maupun penjualan dan mampu menciptakan lingkungan sehat.

\section{DAFTAR PUSTAKA}

1. Arifin HS, Munandar A, Mugnisjah WQ, Budiarti T, Arifin NHS, Pramukanto P. 2007. Homestead Plot Survey on Java. Research Report. Department of Landscape Architecture \& Rural Development Institute (RDI) SeattleUSA.

2. Ashari, Saptana dan Purwanti, TB. 2012. Potensi dan Prospek Pemanfaatan Lahan Pekarangan Untuk Mendukung Ketahanan Pangan. Forum Penelitian Agro Ekonomi. Volum 30 No 1 hal 13-30

3. Desiliyarni. 2003. Vertikultur Teknik Bertanam di Lahan Sempit. Agromedia Pustaka. Depok. 61 hal.
4. Marshall EJP, Moonen AC. 2002. Field margins in northern Europe: their functions and interactions with agriculture. Agric Ecosyst Environ 89:521.

5. Sutarminingsih, C.L. 2003. Vertikultur pola tanam secara vertikal. Bogor : Kanisius. Hal 12-17 